\title{
Applications of Next-Generation Sequencing for Large-Scale Pathogen Diagnoses in Soybean
}

\author{
Gustavo A. Díaz-Cruz, Charlotte M. Smith, Kiana F. Wiebe, Sachi M. Villanueva, Adam R. Klonowski, and Bryan J. Cassone ${ }^{\dagger}$ \\ Department of Biology, Brandon University, Brandon, Manitoba R78 6A9, Canada
}

\begin{abstract}
Soybean (Glycine max) has become an important crop in Manitoba, Canada, with a 10 -fold increase in dedicated acreage over the past decade. Given the rapid increase in production, scarce information about foliar diseases present in the province has been recorded. In order to describe the foliar pathogens affecting this legume, we harnessed nextgeneration sequencing (NGS) to carry out a comprehensive survey across Manitoba in 2016. Fields were sampled during the V2/3 (33 fields) and R6 (70 fields) growth stages, with at least three symptomatic leaves per field collected and subjected to RNA sequencing. We successfully detected several bacteria, fungi, and viruses known to infect soybean, including Pseudomonas savastanoi pv. glycinea, Septoria glycines, and Peronospora manshurica, as well as pathogens not previously identified

in the province (e.g., Pseudomonas syringae pv. tabaci, Cercospora sojina, and Bean yellow mosaic virus). For some microorganisms, we were able to disentangle the different pathovars present and/or assemble their genome sequence. Since NGS generates data on the entire flora and fauna occupying a leaf sample, we also identified residual pathogens (i.e., pathogens of crops other than soybean) and multiple species of arthropod pests. Finally, the sequence information produced by NGS allowed for the development of polymerase chain reaction-based diagnostics for some of the most widespread and important pathogens. Although there are many benefits of using NGS for large-scale plant pathogen diagnoses, we also discuss some of the limitations of this technology.
\end{abstract}

Over the course of millions of years of coevolution, microorganisms and plants have developed intricate and often highly specific biological interactions. Although many of these interplays are commensal or beneficial, some have a detrimental consequence on the host plant, inducing diseases and turning the microorganisms into "pathogens" (Ortíz-Castro et al. 2009; Turner et al. 2013). Under certain circumstances, pathogens can cause significant yield losses to economically important crops, and thus represent a significant threat to regional and even global food security. Each year, a myriad of infectious plant diseases are reported worldwide as a result of multiple factors, including environment, genetic recombination, and anthropogenic introduction (Anderson et al. 2004; Stukenbrock and McDonald 2008). This includes recent regional outbreaks that have resulted in significant regional losses to many economically important crops, including corn (De Groote et al. 2016; Mahuku et al. 2015), wheat (Islam et al. 2016), potato (Abdurahman et al. 2017), tomato (Timilsina et al. 2017), and coffee (Cristancho et al. 2012), among many others. Timely detection of these pathogens represents the first and most important step toward effective disease control and management. As such, multiple diagnostic techniques have been developed to aid in the fight against emerging and established plant pathogens in all crops worldwide (Schumann and D'Arcy 2012; Trigiano et al. 2004).

Over the years, technological and scientific advances have improved the accuracy, sensitivity, and efficiency of pathogen identification, providing a broader range of information and tools to lessen the impact of crop disease (Fang and Ramasamy 2015; Ray et al. 2017). Visual assessments of symptom development and traditional

${ }^{\dagger}$ Corresponding author: B. J. Cassone; cassoneb@brandonu.ca

Funding: This research was supported by the Manitoba Pulse \& Soybean Growers.

*The $\boldsymbol{e}$-Xtra logo stands for "electronic extra" and indicates that seven supplementary tables are published online.

The author(s) declare no conflict of interest.

Accepted for publication 10 January 2019.

(c) 2019 The American Phytopathological Society microbiology techniques (e.g., morphology, motility, sporulation, staining, etc.) are commonly used for pathogen diagnosis. However, these approaches are limited by the expertise of the examiner, the time needed to carry out the tests, and the inability to culture some pathogens (McCartney et al. 2003). More recent serological testing (e.g., immunostrips or enzyme-linked immunosorbent assay [ELISA]) has allowed for the automatization of diagnosis to an extent but is still time-consuming, relies on the availability of specific antibodies, and may produce indecisive results (Lima et al. 2012; López et al. 2003; Narayanasamy 2011). The development of polymerase chain reaction (PCR) revolutionized the identification of microorganisms, providing a faster, more sensitive, and specific technique (Dickinson 2003; Henson and French 1993). Several PCR-based methods have been developed and successfully implemented (e.g., amplified fragment length polymorphism, restriction fragment length polymorphism, nested PCR, multiplex PCR, and quantitative PCR), but all require knowledge of the specific nucleotide sequences of the inferred pathogen (Garibyan and Nidhi 2013).

The relatively recent development of massive parallel nextgeneration sequencing (NGS) technologies has proven invaluable for a wide range of applications across multiple biological disciplines, including plant pathology (Behjati and Tarpey 2013; Studholme et al. 2011; Westermann et al. 2012). Although NGS requires a strong integration of bioinformatics (Conesa et al. 2016), many limitations of the aforementioned approaches for pathogen diagnosis can now be resolved using this technology. Not only does NGS provide superior resolution and sensitivity, but importantly, it also does not rely on previous knowledge of the nucleic acid to be sequenced or require specific antibodies. Several studies have harnessed NGS techniques to expand and enhance the diagnosis of pathogens even before symptoms appear. In virology, NGS has been particularly significant; it has accelerated the identification of viral pathogens in isolated samples of plant tissue and has become sufficiently cost-effective for use in larger-scale disease surveys (Eichmeier et al. 2016; Hadidi et al. 2016; Stewart et al. 2014). Furthermore, NGS has been successfully used to identify viruses infecting soybean plants (Han et al. 2016) and seeds (Groves et al. 2016), as well as viruses infecting their arthropod vectors (Feng et al. 2017). However, its application to other types of pathogenic microorganisms has been limited and has mostly focused on one particular pathogen per study (Chakraborty et al. 2016; Hayden et al. 2014). 
As with all other crops, soybean is affected by multiple abiotic and biotic disorders. Among the biotic issues, foliar diseases are considered a major problem in different parts of the world (Hartman et al. 2015 ) and cause roughly $52 \%$ of yield reductions in the top-eight producing countries (Wrather et al. 2010). Bacterial blight (Pseudomonas savastanoi pv. glycinea), brown spot (Septoria glycines), and Cercospora leaf blight (C. kikuchii) are among the most common foliar diseases of soybean. Other diseases, such as Asian rust (Phakopsora pachyrhizi) and frogeye leaf spot (C. sojina), have also caused important yield reductions in different regions around the world (Cruz et al. 2010; Soares et al. 2015; Yorinori et al. 2005).

In Manitoba, Canada, soybean has experienced a 10-fold increase of land dedicated to the crop during the last decade, increasing from 215,000 to 2,290,000 acres, and it is forecasted to continue its growth in the upcoming years (Statistics Canada 2018). Given the meteoric rise of soybean production, very scarce information about foliar pathogens is recorded for the province, and diagnoses have largely relied on visual observation and the culturing of microorganisms. Thus, the province represents an excellent study site to carry out an NGS-based comprehensive survey of the foliar pathogens infecting the crop. In 2016, we surveyed 81 soybean fields during the production season (V2/3 and R6 growth stages), uncovering a myriad of foliar disease-causing pathogens, including bacteria, fungi, and viruses. Importantly, some of the pathogens detected were not previously identified in the province. For some pathogens, we were even able to unravel the different pathovars present and/or assemble their genome sequence. Since NGS provides information on the entire flora and fauna inhabiting a given leaf sample, we also identified residual pathogens and arthropod pest and vector species. Finally, the sequence information generated by NGS enabled the development of rapid and cost-efficient PCR-based diagnostics for some of the most prevalent and important pathogens. Although the benefits and opportunities of NGS are extensive, we also discuss the potential drawbacks of this technology for large-scale application in plant pathogen diagnoses.

\section{Materials and Methods}

Field survey. Soybean fields were surveyed throughout the Manitoba soybean growing region in late June (V2/3) and in late August (R6) of 2016. In each field, one leaflet sample was taken from plants exhibiting foliar disease symptoms, regardless of its position on the plant. The number of samples collected per field was dependent on the number of plants showing unique foliar symptoms and ranged between 3 and 11 (Fig. 1). Leaf samples were identified with a unique code, then preserved in individual tubes filled with RNA protection buffer (RNAlater; Invitrogen, Carlsbad, CA), transferred to a cooler with ice, and transported to Brandon University (Brandon, MB, Canada). In total, we collected 175 leaf samples from 33 fields in the V2/3 survey and 481 leaf samples from 70 fields in the R6 survey. Twenty-two fields were surveyed at both growth stages. Figure 2 shows the regional distribution of sampled fields across both surveys. The imbalance in the number of fields between surveys is attributed to rainy conditions in the central and eastern regions during late June, making many fields inaccessible.

RNA extraction and RNA sequencing. Total RNA was extracted from each sample using the Plant RNA/DNA Purification Kit (Norgen Biotek, Thorold, ON, Canada), according to the manufacturer's instructions. RNA quantity and quality were assessed using the NanoPhotometer NP80 (Implen Inc., Westlake Village, CA). The samples were then pooled by field and subsequently by region, based on geographical proximity. The pooled samples were sent to the Génome Québec Innovation Centre (Montreal, QC, Canada) for conversion to 11 (V2/3 survey) and 14 (R6 survey) cDNA libraries using the rRNA-depleted (plant) stranded library preparation kit (Kapa

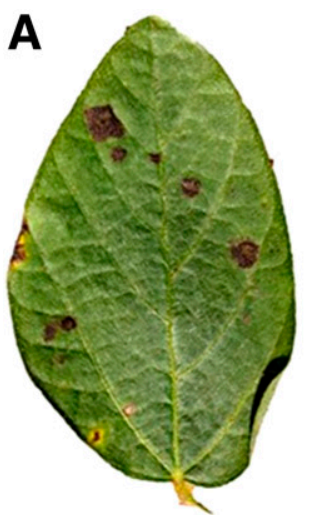

B

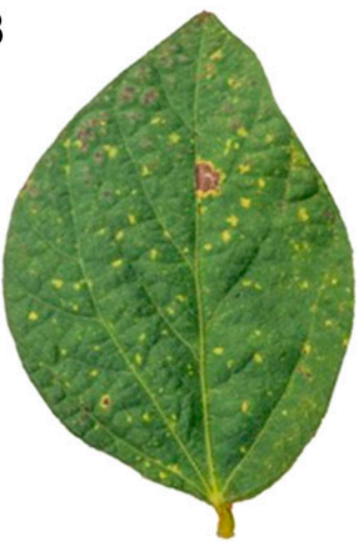

E

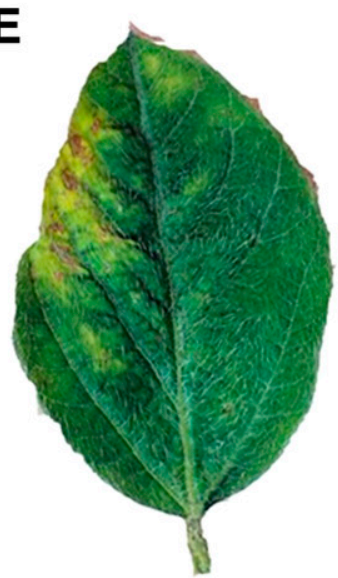

$\mathbf{F}$

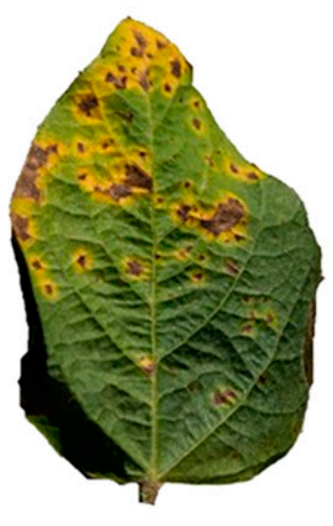

C

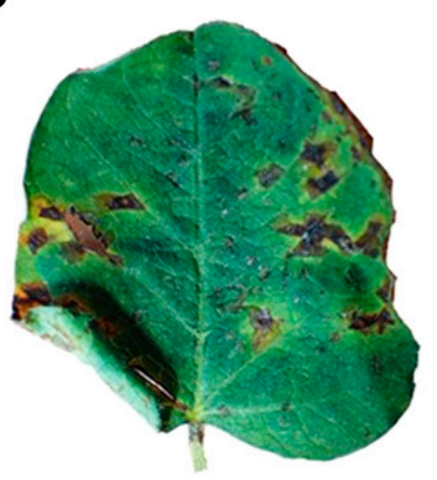

G

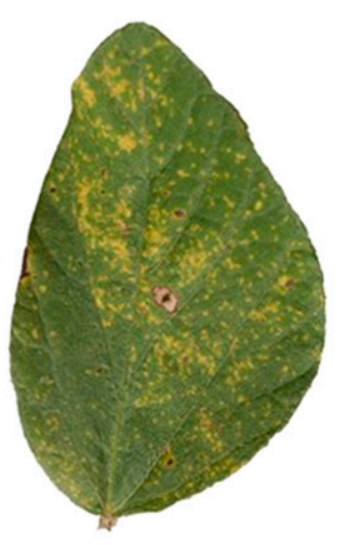

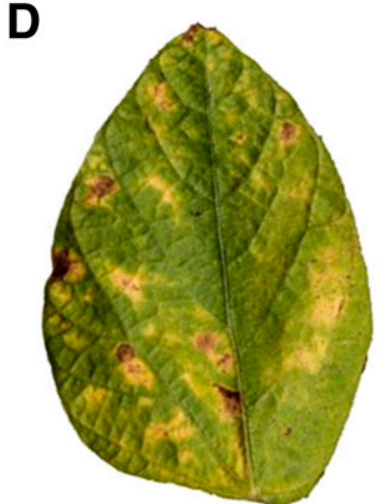

H

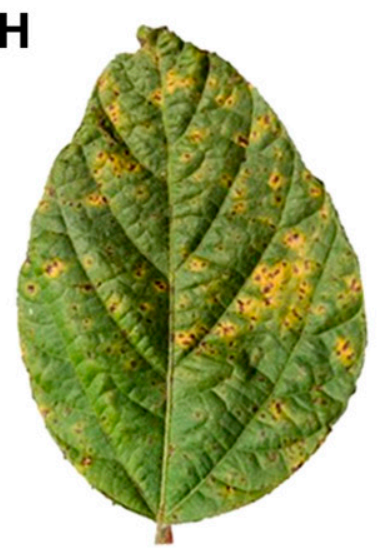

Fig. 1. A representative sample of soybean leaves showing foliar disease symptoms that were collected for pathogen diagnoses by RNA sequencing using the Illumina platform: $\mathbf{A}$, large, dark lesions without chlorosis; $\mathbf{B}$, irregular and chlorotic lesions widely distributed on leaf; $\mathbf{C}$, large, dark lesions with chlorotic edges, associated to main veins; D, large green to yellow lesions with necrotic tissue in the center; $\mathbf{E}$, leaf showing crinkling and yellowing from edge to center; $\mathbf{F}$, irregular and necrotic lesions of various sizes with chlorotic edges; G, small, light green spots widely distributed; and H, small, irregular, dark lesions with or without chlorotic edges. 
Biosystems, Wilmington, MA). The cDNA libraries were then subjected to RNA sequencing in 100-bp paired-end fashion on two lanes of the Illumina HiSeq 2500 platform. The Illumina Analysis Package CASAVA 1.8.2 was used to perform bcl conversion and demultiplexing. Image deconvolution and quality value calculations were carried out using the Illumina GA pipeline (version 1.6). The raw sequence reads are available from the National Center for Biotechnology Information (NCBI) Short Sequence Read Archive under accessions SRR5480332 and SRR5480333 (study SRP105188).

Bioinformatics analysis. Raw reads were imported into CLC Genomics Workbench (version 10.0.1; Qiagen, Hilden, Germany), where adapter indexes and poly(A) tails were trimmed (ambiguous limit $=2$, quality limit $=0.05$ ). Reads were then mapped to the $G$. max Glyma2.0 (56,044 genes) reference cDNA database (retrieved using the BioMart tool in Phytozome) using the following parameters: similarity fraction $=0.95$ and length fraction $=0.7$ (default settings therein). The unmapped reads were assembled de novo using the RNA-SEQ function in CLC and the following parameters: bubble size $=500$, similarity fraction $=0.9$, and length fraction $=0.65(\mathrm{de}-$ fault settings therein). Functional annotation of the resultant contigs was carried out using BLASTn against the NCBI nonredundant (nr) database. A minimum $E$-value $\leq 1 \times 10^{-100}$ with $>90 \%$ sequence similarity and a contig match length $>100$ bp was required for positive species diagnosis. In addition, a minimum of 100 reads for the sequences was used as the cut-off value for a confirmed pathogen.

To gain some insights into the efficacy of NGS in resolving bacterial pathogens to their pathovar, the de novo contigs matching to $P$. savastanoi pv. phaseolicola were further analyzed using local BLASTn $\left(E\right.$-value $\left.\leq 1 \times 10^{-100}\right)$, comparing the contigs against a customized Pseudomonas database, including deposited genomes of P. savastanoi pv. glycinea (GenBank accessions AB106910, AB112554, AB491987, AB683862, AF037443, AF061506, AF093246, AF135163, and AF169828; project accessions AEGG00000001, AEGH00000000, LGLL00000000, LGLM00000000, LGLO00000000, LGLP00000000, and LJQL00000000) and P. savastanoi pv. phaseolicola (GenBank accessions AB237164, AF461559, AJ870974, AY603426, CP000058, CP000059, CP000060, JN655687, JQ365663, KF937496, KT905434, KT905436, KT907498, and NR_ 076360). These represent all of the genomes available in GenBank for $P$. savastanoi pv. glycinea and $P$. savastanoi pv. phaseolicola to date and were included regardless of the assembly level (e.g., complete assembly, scaffolds, contigs). The local BLAST was set to present the top-three results of each contig. The analyses were carried out for each survey independently.

Development of molecular diagnostics. NGS provided a wealth of sequence information for pathogens, epiphytes, and endophytes

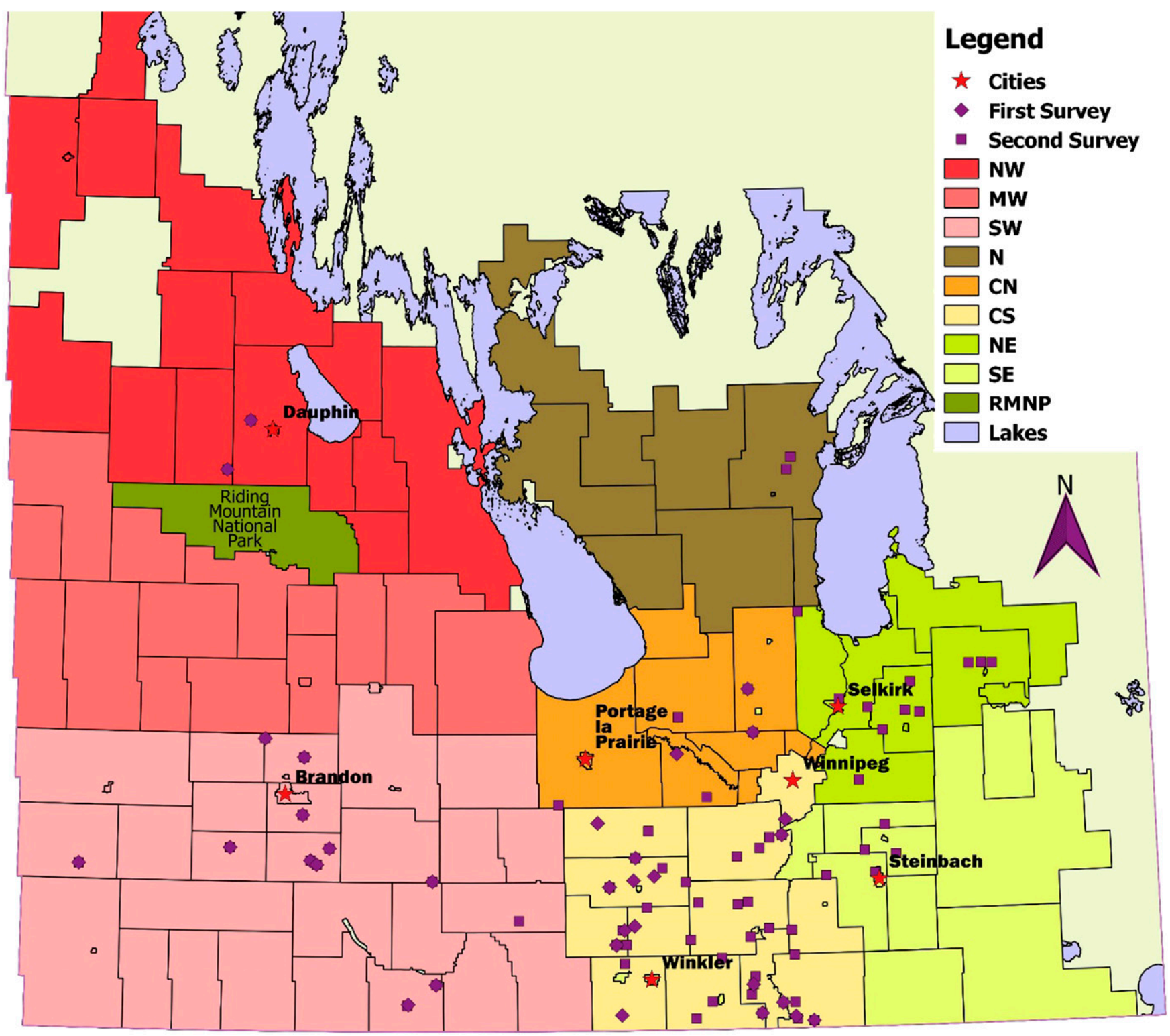

Fig. 2. Regional distribution of soybean fields surveyed in Manitoba in 2016. Surveys were carried out during the V2/3 (diamond) and R6 (square) growth stages. Fields surveyed during both growth stages are denoted with a diamond overlaying a square. 
found in Manitoba, which can be used to design and validate PCR diagnostics in silico for some of the common pathogens. Contig sequences of selected pathogens were manually analyzed for specificity using BLASTn against the nr database. Sequences showing $>96 \%$ within-species identity and low similarity $(<5 \%)$ to other species in their genus were used for primer design using Primer3 (Untergasser et al. 2012). The primer sequences are listed in Supplementary Table $\mathrm{S} 1$.

For validation of PCR diagnostics, cDNA was synthesized from each field pool of the second survey using a high-capacity cDNA Reverse Transcription Kit (Applied Biosystems, Waltham, MA), following the manufacturer's instructions. PCR was performed on the cDNA using each set of primers. The PCR program used included one step of denaturation at $95^{\circ} \mathrm{C}$ for $5 \mathrm{~min}$, followed by 35 cycles composed of $1 \mathrm{~min}$ at $95^{\circ} \mathrm{C}$ (denaturation), $30 \mathrm{~s}$ at $55^{\circ} \mathrm{C}$ (annealing), and $30 \mathrm{~s}$ at $72^{\circ} \mathrm{C}$ (extension). A final 5-min extension step was also included at the end of the program. PCR products were visualized on a $1 \%$ agarose gel stained with ethidium bromide, using an electrophoresis run of $55 \mathrm{~min}$ at $110 \mathrm{~V}$.

PCR products from all different sets of primers were purified using the PureLin Quick PCR Purification Kit (Invitrogen, Lithuania) following the manufacturer's instructions and were later sent to the Centre for Applied Genomics (Toronto, ON, Canada) for Sanger sequencing. The sequences were visualized using FinchTV (version 1.4.0) and then compared in the NCBI nr database using BLASTn to validate the identified pathogens. The specificity of each primer set was further validated on soybean samples positive for the other common pathogens that were subjected to PCR diagnostic development.

\section{Results}

NGS as a tool for pathogen identification. Foliar diseases can be very destructive to soybean plants, and control is exceedingly difficult when there is little to no information on the pathogens established in the production areas. To explore the efficacy of NGS in identifying different types of pathogens, 25 cDNA libraries representing $>650$ symptomatic leaf samples (e.g., necrotic and chlorotic spots, crinkling, regular and irregular lesions, leaf deformation, streaking, specks, discoloration) from 81 Manitoba soybean fields surveyed twice in 2016 (V2/3 and R6 growth stages) were subjected to RNA sequencing. More than 700 million paired-end reads of 100 bp were generated, of which $\sim 11 \%$ on average was not of soybean origin. The nonsoybean read subset of each cDNA library was assembled de novo into contigs (see Supplementary Table S2). Each contig was functionally annotated using BLASTn and then classified to the species level (where possible) based on the most significant match to the nr database. Our results show an array of different types of microorganisms associated with symptom development on soybean across Manitoba in both the early and later stages of development.
Pathogens previously reported in Manitoba. Table 1 summarizes the Canadian Plant Disease Surveys (CPDSs) of the last 15 years specific to Manitoba, using visual examination, culturing on culture medium, ELISA, and Agdia ImmunoStrips (Desjardins 2010; Desjardins and Bisht 2011; Desjardins et al. 2002, 2003 , 2004, 2005, 2006, 2007, 2008, 2009, 2012, 2013, 2014, 2015; Platford and Desjardins 1999, 2000; Platford and Kurtz 1997, 1998; Pradhan et al. 2016, 2017). These surveys were used as baseline data to determine which pathogens were previously reported in Manitoba. Of the 10 foliar diseases reported previously, nine of the causative agents were identified in our survey. This included pathogens of all five diseases found in each of the past 4 years (brown spot, downy mildew, anthracnose, bacterial blight, and Alternaria leaf spot), two others that have been sporadically reported (Cercospora blight and leaf spot), and two found in only one survey (bacterial pustule, 2003; gray mold, 2010). The only previously reported disease where the causative agent was not detected in our survey was Soybean mosaic virus (SMV), which was only found in 2010 .

New pathogens to Manitoba. We previously reported two viral pathogens detected in our surveys that were not previously known to infect soybean: Brome mosaic virus (BMV; genus Bromovirus) (Díaz-Cruz et al. 2018) and Tobacco necrosis virus strain D (TNV-D; genus Betanecrovirus) (Díaz-Cruz et al. 2017). A group of soybean pathogens that have been reported in other regions but not in the province of Manitoba were also identified (Table 2), including Bean yellow mosaic virus (BYMV; genus Potyvirus) (Tu 1986), C. sojina (frogeye leaf spot) (Anderson and Tenuta 2001), Pleospora herbarum (leaf blight), and Boeremia exigua var. exigua (leaf spot) (Hartman et al. 2015)

Disentangling the disease-causing species. Previous surveys in Manitoba were based on visual assessment and culturing. Consequently, the putative diseases are reported but the causative agent is rarely identified to the species level. NGS allows us to elucidate this by obtaining multiple sequences and reads that match to specific organisms, provided the genomic resources are available. Among the diseases that have not been reported to the species level is anthracnose, caused by the genus Colletotrichum; in the current study, two species previously identified in other regions but not in Manitoba were detected. Similarly, the bacterial genus Pseudomonas has not yet been fully identified to the species level in some soybean isolates but in this case, $P$. cichorii (a well-known pathogen) was detected.

In many cases, the sensitive and powerful nature of NGS also allowed for identification of pathogens to the pathovar level. We used $P$. savastanoi as an example of this. Contigs matching $P$. savastanoi pv. phaseolicola (syn. $P$. syringae pv. phaseolicola) were compared using desktop-downloaded BLASTn against a customized database of nucleotide sequences and genomes of varying completeness for P. savastanoi pv. glycinea (syn. P. syringae pv.

Table 1. Foliar pathogens previously reported in Manitoba soybean, based on Canadian Plant Disease Surveys (2001 to 2015) ${ }^{\mathrm{a}}$

\begin{tabular}{|c|c|c|c|c|c|c|c|c|c|c|c|c|c|c|c|c|}
\hline \multirow[b]{2}{*}{ Disease } & \multirow[b]{2}{*}{ Pathogen } & \multicolumn{15}{|c|}{ Year of report } \\
\hline & & 2001 & 2002 & 2003 & 2004 & 2005 & 2006 & 2007 & 2008 & 2009 & 2010 & 2011 & 2012 & 2013 & 2014 & 2015 \\
\hline Brown spot & Septoria glycines & & $\mathrm{X}$ & $\mathrm{X}$ & & & $\mathrm{X}$ & & $\mathrm{X}$ & $\mathrm{X}$ & & $\mathrm{X}$ & $X$ & $\mathrm{X}$ & $\mathrm{X}$ & $X$ \\
\hline Downy mildew & $\begin{array}{l}\text { Peronospora } \\
\text { manshurica }\end{array}$ & & $\mathrm{X}$ & $\mathrm{X}$ & $\mathrm{X}$ & $\mathrm{X}$ & & $\mathrm{X}$ & $\mathrm{X}$ & $\mathrm{X}$ & $\mathrm{X}$ & $\mathrm{X}$ & $\mathrm{X}$ & $\mathrm{X}$ & $\mathrm{X}$ & $\mathrm{X}$ \\
\hline Bacterial pustule & $\begin{array}{l}\text { Xanthomonas } \\
\text { axonopodis pv. } \\
\text { glycines }\end{array}$ & & & $\mathrm{X}$ & & & & & & & & & & & & \\
\hline Cercospora blight & Cercospora kikuchii & & & & & & & & & $\mathrm{X}$ & & & & & $\mathrm{X}$ & \\
\hline Leaf spot & Phyllosticta spp. & & & & & & & & & $\mathrm{X}$ & $\mathrm{X}$ & $\mathrm{X}$ & $\mathrm{X}$ & & & $\mathrm{X}$ \\
\hline Anthracnose & Colletotrichum spp. & & & & & & $\mathrm{X}$ & & & & $\mathrm{X}$ & $\mathrm{X}$ & $\mathrm{X}$ & $\mathrm{X}$ & $\mathrm{X}$ & $\mathrm{X}$ \\
\hline Gray mold & Botrytis cinerea & & & & & & & & & & $\mathrm{X}$ & & & & & \\
\hline Bacterial blight & Pseudomonas sp. & $\mathrm{X}$ & $\mathrm{X}$ & $\mathrm{X}$ & $\mathrm{X}$ & & $\mathrm{X}$ & & $\mathrm{X}$ & $\mathrm{X}$ & $\mathrm{X}$ & $\mathrm{X}$ & $\mathrm{X}$ & $\mathrm{X}$ & $\mathrm{X}$ & $\mathrm{X}$ \\
\hline Seed discoloration & Soybean mosaic virus & & & & & & & & & & & & & $\mathrm{X}$ & & \\
\hline Alternaria leaf spot & A. alternata & & & & & & & & & & & & & & $\mathrm{X}$ & $\mathrm{X}$ \\
\hline
\end{tabular}

a Positive years for each pathogen are denoted with an "X" and the disease caused by each pathogen is also shown. With the exception of Soybean mosaic virus, all pathogens were found in our 2016 surveys. Sources are as follows: Desjardins (2010), Desjardins and Bisht (2011), Desjardins et al. (2001, 2002, 2003, 2004, 2005, 2006, 2007, 2008, 2009, 2012, 2013, 2014, 2015), Platford and Desjardins (1999, 2000), Platford and Kurtz (1997, 1998), and Pradhan et al. (2016, 2017). 
glycines) and $P$. savastanoi pv. phaseolicola. Focusing on the topthree BLAST hits of contigs across the V2/3 and R6 surveys, 55\% had one $P$. savastanoi pv. glycinea and two $P$. savastanoi pv. phaseolicola matches, whereas $44 \%$ had all three matches to $P$. savastano $i$ pv. glycinea (Supplementary Table S3). Other combinations of matches did not exceed $1 \%$.

Nonfoliar soybean pathogens. Most pathogens preferentially infect and spread to specific tissues of the host plant, and they are generally classified as pathogens of the leaf, stem, or root. In several regions of our survey, NGS identified soybean pathogens that are known to predominately infect tissues other than leaves. Two species within the Diaporthe genus, D. eres and D. longicolla (causal agents for seed and stem diseases), appeared as part of the survey in multiple regions. Interestingly, Phytophthora sojae was detected on leaves across all of the regions of study, despite being a root pathogen (Supplementary Table S4).

Residual pathogens. In many cases, foliar pathogens overwinter in the soil and can reinfect next year's crop. Crop rotation helps protect against this, as many pathogens are host specific and cannot successfully invade the foliar tissues of the newly planted crop. Therefore, we explored our contig lists for pathogens known to infect other crops planted in the province but not soybean; this group is referred to hereafter as "residual pathogens" (Supplementary Table S5). The pathogens detected are parasitic predominantly to cereals (e.g., wheat, barley, maize, oat, rye) and brassicas (e.g., canola) but also to other groups such as legumes and trees. Some genera with several species detected included Bipolaris (maize) (Manamgoda et al. 2014), Colletotrichum (multiple crops) (Cannon et al. 2012), Leptosphaeria (canola) (Fernando et al. 2016), Phaeosphaeria and Pyrenophora (wheat) (Gilbert and Woods 2001), and Xanthomonas (canola) (Vicente and Holub 2013).

Arthropods. Many arthropods cause damage to host plants through their feeding behavior, by serving as vectors that spread pathogens plant to plant. Since NGS provides information on the leaf and all of the organisms associated with a given leaf sample, we also identified sequencing matching arthropod pest and vector species in both surveys (Supplementary Table S6). Members of the Lepidoptera order (Bombyx mori, Helicoverpa zea, Heliothis virescens, Spodoptera exigua, S. frugiperda, Trichoplusia $n i$ ) were found only during the early survey (presumably coinciding with their wingless larval stages), whereas the member of Homoptera (Acyrthosiphon pisum) was present only in the second survey. Species within the orders Thysanoptera (Frankliniella occidentalis, F. tritici) and Trombidiformes (Tetranychus pueraricola, Tetranychus urticae) were present in both surveys. At least 13 of the identified arthropod species are known pests of soybean (Abd El-Wahab 2016; Gotoh et al. 2004; Hartman et al. 2015; Keough et al. 2016; Nikolova et al. 2014; Pobozniak 2011; Suekane et al. 2012; Viteri et al. 2010). Overall, the arthropods were found in several locations throughout the province but were predominately found in the southwestern and central regions.
Whole genome sequences. The baseline sequence data generated using NGS are assembled into larger sequences that reflect the mRNA sequences expressed by the pathogens. If the pathogen is a virus with a relatively small RNA genome, it is often possible to generate its complete or near-complete genome. As such, we previously reported the whole genome sequence of TNV-D, which was isolated from a leaf sample collected during our V2/3 survey (Díaz-Cruz et al. 2017). Similarly, the contig sequences for BYMV covered $~ 92 \%$ of the 9.5 Mb genome available in NCBI (GenBank accession KF632713), with $~ 97 \%$ identity. For BMV, the coverage was lower at $41 \%$, but the contigs analyzed included all three RNA segments of the virus with no less than 99\% similarity (GenBank accession DQ530423).

Development of molecular diagnostics. Although NGS has proven to be an exceptional tool, it is impractical for use as a routine diagnostic. A major benefit of our approach is that it generated DNA sequence data for strains of pathogens found in Manitoba. We used this information to develop PCR-based diagnostics for seven of the most prevalent and important soybean foliar pathogens present in the province. Each diagnostic was tested and validated on 70 fields from our 2016 survey (Supplementary Table S7). These new tools will allow for fast, sensitive, reliable, and cost-efficient pathogen identification in future provincial surveys and in isolated diagnoses.

\section{Discussion}

Similar to other crops, soybean is susceptible to multiple types of pathogens (e.g., bacteria, fungi, viruses, oomycetes), some of which threaten the normal development of plants and could severely impact yield. Many of the traditional approaches for pathogen detection (e.g., visual observation of symptoms, culturing) are not sensitive and/or are prone to misdiagnosis. Newer diagnostic tools (e.g., PCR, ELISA) are more accurate and sensitive but require a priori knowledge of the pathogens present. In this study, we assessed the capabilities of NGS (RNA) in identifying diverse microorganisms inhabiting soybean leaves. More than 650 samples exhibiting foliar symptoms of disease were collected across Manitoba, Canada in June (V2/3) and August (R6) of 2016. As discussed below, we identified bacterial, oomycete, fungal, and viral pathogens, including some microorganisms that were not previously reported in the province. NGS was sensitive enough to uncover the pathovars present for some of our pathogens, assemble complete or nearcomplete genome sequences of the identified RNA viruses, and provide information on the residual pathogens and arthropod pest and vector species found in the fields. Although many nonpathogenic microorganisms were also detected, it was not the intent of this study to describe them; thus, they were omitted from the data set.

Annual CPDSs identify soybean pathogens in Manitoba based mostly on visual assessment of the disease symptoms and culturing techniques. Consequently, several of the reported causal disease

Table 2. Foliar pathogens identified in Manitoba soybean in 2016 by next-generation sequencing, which were not previously reported in the province ${ }^{\mathrm{a}}$

\begin{tabular}{|c|c|c|c|c|c|c|c|c|c|c|c|c|c|}
\hline \multirow[b]{3}{*}{ Type } & \multirow[b]{3}{*}{ Pathogen } & \multirow[b]{3}{*}{ Disease } & \multicolumn{11}{|c|}{ Region } \\
\hline & & & \multicolumn{2}{|c|}{ NW } & \multicolumn{2}{|c|}{ SW } & \multirow{2}{*}{ 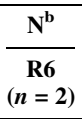 } & \multicolumn{2}{|c|}{$\mathbf{C N}$} & \multicolumn{2}{|c|}{ CS } & \multirow{2}{*}{ 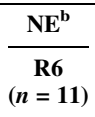 } & \multirow{2}{*}{ 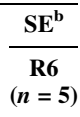 } \\
\hline & & & $\begin{array}{c}\mathrm{V} 2 / 3 \\
(n=2)\end{array}$ & $\begin{array}{c}\text { R6 } \\
(n=2)\end{array}$ & $\begin{array}{c}\mathrm{V} 2 / 3 \\
(n=11)\end{array}$ & $\begin{array}{c}\text { R6 } \\
(n=12)\end{array}$ & & $\begin{array}{c}\mathrm{V} 2 / 3 \\
(n=3)\end{array}$ & $\begin{array}{c}\mathrm{V} 2 \\
(n=5)\end{array}$ & $\begin{array}{c}\mathrm{V} 2 / 3 \\
(n=16)\end{array}$ & $\begin{array}{c}\text { R6 } \\
(n=33)\end{array}$ & & \\
\hline \multirow[t]{6}{*}{$\overline{\text { Fungi }}$} & Alternaria tenuissima & Leaf and stem spot & - & + & + & + & + & - & + & + & + & + & + \\
\hline & Cercospora sojina & Frogeye & - & + & + & + & + & - & + & + & + & + & + \\
\hline & Colletotrichum gloeosporioides & Anthracnose & - & - & - & - & - & - & - & - & + & - & - \\
\hline & Colletotrichum graminicola & Anthracnose & - & - & - & - & - & - & - & - & + & - & - \\
\hline & Diaporthe eres & Seed decay & - & - & - & - & - & - & - & - & + & + & - \\
\hline & Pleospora herbarum & Leaf blight & - & - & - & - & - & - & - & + & - & - & - \\
\hline \multirow[t]{2}{*}{ Bacteria } & Pseudomonas cichorii & Leaf spot & - & - & + & - & - & - & - & + & + & + & + \\
\hline & Pseudomonas syringae pv. tabaci & Wildfire & - & + & + & - & - & + & - & + & + & + & - \\
\hline Virus & Bean yellow mosaic virus & Mosaic of legumes & - & - & - & + & - & - & - & - & - & - & - \\
\hline
\end{tabular}

a The distribution of pathogens is categorized by region (NW = Northwest, $\mathrm{SW}=$ Southwest; N = North, CN = Northcentral, CS = Southcentral, NE = Northeast, and $\mathrm{SE}=$ Southeast), where a plus sign indicates a positive diagnosis (i.e., pathogen is present) and a minus sign indicates a negative diagnosis. The number of fields surveyed per region is also displayed. V2/3 and R6 represent the growth stage of soybean surveyed.

b Samples from these regions were taken only during the R6 survey. 
agents have only been identified to their genus: bacterial blight (Pseudomonas spp.), leaf spot (Phyllosticta spp.), and anthracnose (Colletotrichum spp.). Application of NGS allowed for unparalleled resolution of the species present in Manitoba that are responsible for these diseases. Indeed, two Colletotrichum species (Colletotrichum gloeosporioides and Colletotrichum graminicola) and two Pseudomonas species ( $P$. savastanoi and $P$. syringae) appear to contribute to anthracnose and bacterial blight in the province, respectively. Although the CPDS attributed leaf spot to Phyllosticta and we did not identify any species in this genus, other soybean pathogens conferring similar disease symptoms were present (e.g., A. alternata, Boeremia exigua). In particular, the Boeremia and Phyllosticta genera comprise closely related, morphologically similar Phoma-like species (Chen et al. 2015; de Gruyter et al. 2013), which can easily lead to misdiagnosis.

Of the seven pathogens reported by CPDSs to the species level, six were corroborated by NGS; the exception was SMV, which has not been reported in the province since 2013. Plants developing from infected seed serve as the primary inoculum for insect vectors that disseminate the pathogen to healthy plants (Domier et al. 2007; Porto and Hagedorn 1975). Given the relatively high titers of SMV RNA in infected leaves (Díaz-Cruz and Cassone 2018) and the absence of observable disease symptoms corresponding to SMV in our samples, it is probable that SMV was absent from the fields used during our surveys. The most likely explanation for the absence of SMV in this study is perhaps some combination of the use of clean seed in the fields surveyed, low incidence of the disease, and insufficient sampling power. A more targeted study is needed to better infer this.

Although the CPDS makes no formal attempts in identifying bacterial pathogens to their pathovar, we demonstrated with Pseudomonas that pathogens can even be delineated to their pathovar if appropriate genomic resources are available and there are regions of the genome showing sufficient genetic differentiation. This information is valuable because different pathovars could induce identical symptoms in infected plants but have a different genetic composition, as a result of recombination and development of different strains (Nowell et al. 2016).

The primary goal of this study was to assess the ability of NGS to detect pathogens not previously reported in Manitoba. We hypothesized that because soybean is a relatively new crop in the province and has dramatically expanded in acres planted, there could be several pathogens that are in the province but have not yet been reported. With sufficient sequencing coverage, NGS provides a snapshot of all the microorganisms inhabiting a given leaf sample. As expected, we found a myriad of pathogens new to Manitoba; these may have already been established in the region but not identified by traditional surveys or may represent new invasions in 2016. Among these were two bacteria of the pseudomonads: $P$. cichorii, reported as a pathogen of soybean only in South Korea (Yu and Lee 2012), and P. syringae pv. tabaci, causal agent of tobacco wildfire, previously detected in regions of Canada (Anderson and Tenuta 2001). New fungal pathogens include A. tenuissima, a pathogen that has more impact on seed germination but can also live on and damage foliar tissue (Jasnić et al. 2011; Larran et al. 2002; Shortt et al. 1982; Thomma 2003). C. sojina, causal agent of frogeye leaf spot, was also detected. Previously reported as a minor pathogen in Canada (Wrather and Koenning 2006), C. sojina has shown more importance in the United States as a result of fungicide resistance (Zhang et al. 2012). Stemphylium leaf blight, a minor disease caused by Pleospora herbarum (Hartman et al. 2015), was identified as well. A report on fungal communities found that Pleospora herbarum is part of healthy soybean leaves (Larran et al. 2002), but pathogenic reports are limited (Caudillo-Ruiz et al. 2017). Finally, BYMV (genus Potyvirus) was the only newly detected viral pathogen. In soybean, it causes yellow mottling and typical mosaic symptoms (Campos et al. 2014; Golnaraghi et al. 2004). Although not previously reported to infect soybean in Manitoba, BYMV has been found to infect faba bean in the province (Frowd and Bernier 1977).

A particularly interesting finding was that soybean fungal pathogens known to infect nonfoliar tissues were also detected in foliar tissues. Phytophthora sojae is a severe root and stem pathogen (Tyler 2007) and was recovered from most regions. However, under certain conditions, the pathogen may move up to the foliar tissue (Cabrera et al. 2009). D. eres and D. longicolla are part of a genus containing multiple species infecting soybean (Gomes et al. 2013; Santos et al. 2011; Udayanga et al. 2015) and have been reported to cause seed decay (Petrović et al. 2015) and stem disease, respectively. Future studies are needed to discern whether they are truly invading the tissues or simply attaching onto the surfaces of leaves or are the result of soil contamination, or less likely, misdiagnosis caused by the database used as reference.

Prior to the survey, we had no expectations on the ability of NGS to generate information on residual pathogens or arthropod species. A total of 61 bacterial, fungal, and oomycete microorganisms known to infect crops other than soybean were identified. This included pathogens of other economically important crops in Manitoba, such as canola, wheat, and maize. The presence of residual pathogens in soybean fields is likely attributable to the proximity of other crops, spontaneous plants from previous crop cycles in the same field, pathogens with overwintering capacities (Duczek et al. 1999), as well as weeds, which often represent the main reservoir of pathogens (Wisler and Norris 2005). Pathogenicity tests are required to determine the risk these microorganisms pose to both soybean and other crops, as well as the potential of soybean as an inoculum source. Nonetheless, the activity of certain pathogens in soybean fields may advise growers of crops that may or may not be desirable to plant in the subsequent year. Consequently, there may be benefit to incorporating NGS into crop rotation analysis, to determine the presence of specific pathogens, in similar fashion to the work carried out in this study.

The detection of arthropods in our samples shows that NGS can also extend to pests that cause damage by feeding or spreading pathogens among plants. NGS has been shown to be more accurate, sensitive, and effective than Sanger sequencing for barcoding of arthropods (Shokralla et al. 2015). In addition, the analysis of potential vectors has aided in the detection of plant pathogens (Nouri et al. 2016). We were able to detect sequences belonging to members of four different orders: Homoptera, Lepidoptera, Thysanoptera, and Trombidiformes. The identified organisms that are problematic for soybean include the fall armyworm ( $S$. frugiperda) (da Silva et al. 2017; Peruca et al. 2018), five species of genus Frankliniella (Pobozniak 2011), and three species in the Tetranychus genus (Gotoh et al. 2004; Nikolova et al. 2014; Suekane et al. 2012). Compared with the report of insects affecting soybean in 2016 for the province of Manitoba, there is consistency with the presence of spider mites (Tetranychus spp.), whereas our survey did not detect soybean aphid (Aphis glycines) or green cloverworm (Hypena scabra) (Gavloski 2016).

The amount of short-read sequence data generated by NGS has increased dramatically (Muir et al. 2016; Zhang et al. 2011). It is now possible to produce hundreds of millions of reads in a single sequencing run and even generate complete or near-complete genomes of microorganisms inhabiting different host tissues (Cassone et al. 2015). Previously, we reported the assembly of the viral pathogen TNV-D (Díaz-Cruz et al. 2017), facilitated by the high amount of reads and full coverage compared with other genomes available. In this study, a similar situation was determined for BYMV and BMV, although we could not achieve complete coverage. This technology has been useful to detect and describe novel mycoviruses associated with soybean leaves (Marzano and Domier 2016). In order to improve genome assembly from plant material, a minimum coverage of $30 x$ and different RNA extraction methods have been proposed (Kehoe et al. 2014). Although our study used RNA sequencing, DNA isolation and sequencing would likely result in draft assemblies of bacterial and fungal pathogens.

In addition to genome assemblies, the large volume of sequence information produced by NGS can be filtered to identify genes of specific pathogens that are highly expressed during the infection process. These genes, if conserved, can be targeted for primer development and robust PCR-based diagnostics that are specific to the strains found in a given geographic region. Based on our surveys, our primers were designed and optimized for seven relevant pathogens in 
Manitoba that infect soybean. However, implementing the primers designed through NGS in diagnostic clinics would require a more thorough validation of their sensitivity and specificity to the targeted pathogen across its range distribution. Furthermore, primers developed for genomic DNA would likely be more ideal, as this would omit the reverse transcription step.

Although the benefits of using NGS have been discussed, there are several limitations of implementing the technology for large-scale diagnoses. In terms of bacterial or fungal pathogens, NGS can only be used to detect their presence in a given sample. Additional assays are required to isolate the causative organisms and determine whether they are truly pathogenic. The technology also relies on the availability of genomic resources. Although soybean pathology sequence data have been rapidly expanding, many important pathogens do not have complete genome sequences currently available and some have extremely limited resources. In these cases, the diagnoses must be inferred based on the sequences of closely related organisms that have more accessible nucleic acid resources. In our study, the causal agent of downy mildew (Peronospora manshurica) had only five nucleotide sequences reported in the NCBI database at the moment of the analysis, but four genomes in the genus Peronospora were available. Other examples in our results where genomic resources may play a significant role for the proper identification of pathogens include the Septoria/Mycosphaerella group (Crous 2009; Soares et al. 2015; Verkley et al. 2013; Videira et al. 2017), the Xanthomonas axonopodis group (Constantin et al. 2016), the Phomopsis/Diaporthe complex (Gomes et al. 2013; Mengistu et al. 2014; Nevena et al. 1997; Udayanga et al. 2014, 2015), and Phoma-like species (Chen et al. 2015; de Gruyter et al. 2013).

The same limitation applies for pathovar identification. A relatively large number of reads and contigs were assigned to the bacterial pathogen $P$. savastanoi pv. phaseolicola, which has minor significance to soybean (Hartman et al. 2015). In contrast, the number of reads and contigs assigned to the more important $P$. savastanoi pv. glycinea was much lower. When the BLAST analysis was done for this study, the NCBI nr database had a P. savastanoi pv. phaseolicola complete genome available, whereas $P$. savastanoi pv. glycinea presented only independent genes. A previous study on the P. savastanoi pv. glycinea genomes determined that $P$. savastanoi $\mathrm{pv}$. phaseolicola strain 1448A is the most closely related pseudomonads genome to two $P$. savastanoi pv. glycinea genomes, sharing more than 4,500 genes (Qi et al. 2011). In this particular case, the similarity of sequences seems to play a significant role in the outcome of the analysis. Since the group P. syringae/P. savastanoi is divided into pathovars based on the biological interaction with host plants rather than genomic diversity, the use of NGS is incomplete for identification, requiring other methods of confirmation before a final report is made for each microorganism.

Although NGS generates data on the entire biota inhabiting a host, in most cases the majority of reads are host derived. Our study was no exception, as nearly $90 \%$ of reads were of soybean origin. This means that the high-throughput nature of NGS is effectively reduced. This must be taken into consideration in the experimental design, as it may require multiple sequencing runs to achieve the desired resolution. A potential solution is to use prokaryote enrichment kits to facilitate the detection of bacterial pathogens; this was not applicable in our study, given the goal of identifying diverse organisms. In terms of analysis, although the application for plant pathogen detection does not necessarily require the use of a plant reference genome, its availability expedites the de novo assembly and functional annotation processes. Additional issues are related to the database (in our case, NCBI nr) used for diagnosis and include error rates and sequences matching to multiple organisms. The latter is particularly problematic for NGS studies based on internal transcribed spacer (ITS)/16S sequencing. For global RNA sequencing approaches, the bulk of generated sequences are considerably more conserved and assembled into larger contigs, thus providing better resolution at the species level.

Other issues that should be considered for larger-scale application of NGS are the associated costs and expertise required for analysis.
Although NGS costs have declined dramatically and NGS now represents a relatively cost-effective tool, it is still considerably more expensive than more traditional diagnostic approaches and would therefore be difficult to justify implementing NGS into long-term annual surveys. A cost-effective alternative could be to carry out $16 \mathrm{~S}$ or ITS amplicon sequencing for surveys focused on only fungal or bacteria species. In terms of time, NGS requires multiple molecular approaches, sequencing, and high-throughput analysis, which justifiably take much longer than a PCR or serological test and thus would not be recommended if immediate diagnosis is needed. Finally, most of the freely accessible software used for data analysis requires some skill at computational programming. There is some graphical interface-based software available as used in this study; however, licensing and support fees can be expensive.

In our study, we successfully used NGS to identify multiple foliar microorganisms with pathogenic potential present in soybean across the province of Manitoba, Canada. No prior knowledge of these microorganisms was required for identification, but the accuracy and precision of the method relied on the availability of genomic resources accessed in NCBI. This situation highlights the importance of further research in genomes and transcriptomes of soybean pathogens, to increase the chances of proper identification. In addition, we were able to detect pathogenic microorganisms of crops other than soybean, suggesting that NGS could be used in the analysis of residual pathogens, a major concern for crop rotation strategies. We were also able to detect arthropod sequences, meaning that further studies in the epidemiology of viral diseases could include NGS to confirm the identity of potential vectors. Taken collectively, although NGS is not perfect, it represents a promising option for large-scale disease surveys.

\section{Acknowledgments}

We thank Manitoba Pulse \& Soybean Growers (MPSG) and Manitoba Agriculture members for support in the sample collection. We also thank Kristen MacMillan and Laryssa Stevenson of MPSG for valuable feedback. Finally, we are grateful to Dr. Debra McLaren for critical comments on the manuscript.

\section{Literature Cited}

Abd El-Wahab, A. S. 2016. Survey, seasonal abundance of thrips species and first record of two thrips species associated with soybean and weed plants in Egypt. Egypt. Acad. J. Biol. Sci. A Entomol. 9:49-68.

Abdurahman, A., Griffin, D., Elphinstone, J., Struik, P. C., Schulz, S., SchulteGeldermann, E., and Sharma, K. 2017. Molecular characterization of Ralstonia solanacearum strains from Ethiopia and tracing potential source of bacterial wilt disease outbreak in seed potatoes. Plant Pathol. 66:826834.

Anderson, P. K., Cunningham, A. A., Patel, N. G., Morales, F. J., Epstein, P. R. and Daszak, P. 2004. Emerging infectious diseases of plants: Pathogen pollution, climate change and agrotechnology drivers. Trends Ecol. Evol. 19: 535-544.

Anderson, T. R., and Tenuta, A. U. 2001. Diseases of soybean in Ontario and estimated yield losses, 1994, 1996-2000. Can. Plant Dis. Surv. 2001. 81: 133-135.

Behjati, S., and Tarpey, P. S. 2013. What is next generation sequencing? Arch. Dis Child. Educ. Pract. Ed. 98:236-238.

Cabrera, M. G., Gutiérrez, S. A., and Cúndom, M. A. 2009. Tizón por Phytophthora sojae en cultivos de soja de la provincia del Chaco (Argentina). Summa Phytopathol. 35:75.

Campos, R. E., Bejerman, N., Nome, C., Laguna, I. G., and Rodríguez Pardina, P. 2014. Bean yellow mosaic virus in soybean from Argentina. J. Phytopathol. 162:322-325.

Cannon, P. F., Damm, U., Johnston, P. R., and Weir, B. S. 2012. Colletotrichum current status and future directions. Stud. Mycol. 73:181-213.

Cassone, B. J., Wenger, J. A., and Michel, A. P. 2015. Whole genome sequence of the soybean aphid endosymbiont Buchnera aphidicola and genetic differentiation among biotype-specific strains. J Genomics 3:85-94.

Caudillo-Ruiz, K. B., Bhadauria, V., and Banniza, S. 2017. Aetiology of stemphylium blight on lentil in Canada. Can. J. Plant Pathol. 39:422-432.

Chakraborty, S., Britton, M., Martínez-García, P. J., and Dandekar, A. M. 2016. Deep RNA-Seq profile reveals biodiversity, plant-microbe interactions and a large family of NBS-LRR resistance genes in walnut (Juglans regia) tissues. AMB Express 6:12

Chen, Q., Jiang, J. R., Zhang, G. Z., Cai, L., and Crous, P. W. 2015. Resolving the Phoma enigma. Stud. Mycol. 82:137-217.

Conesa, A., Madrigal, P., Tarazona, S., Gomez-Cabrero, D., Cervera, A., McPherson, A., Szcześniak, M. W., Gaffney, D. J., Elo, L. L., Zhang, X., 
and Mortazavi, A. 2016. A survey of best practices for RNA-seq data analysis (erratum published in Genome Biol. 2016;17:181). Genome Biol. 17:13.

Constantin, E. C., Cleenwerck, I., Maes, M., Baeyen, S., Van Malderghem, C., De Vos, P., and Cottyn, B. 2016. Genetic characterization of strains named as Xanthomonas axonopodis pv. dieffenbachiae leads to a taxonomic revision of the $X$. axonopodis species complex. Plant Pathol. 65:792-806.

Cristancho, M. A., Rozo, Y., Escobar, C., Rivillas, C. A., and Gaitán, A. L. 2012. Outbreak of coffee leaf rust (Hemileia vastatrix) in Colombia. New Dis. Rep. 25:19.

Crous, P. W. 2009. Taxonomy and phylogeny of the genus Mycosphaerella and its anamorphs. Fungal Divers. 38:1-24.

Cruz, C. D., Mills, D., Paul, P. A., and Dorrance, A. E. 2010. Impact of brown spot caused by Septoria glycines on soybean in Ohio. Plant Dis. 94:820-826.

da Silva, D. M., Bueno, A. de F., Andrade, K., Stecca, C. dos S., Neves, P. M. O. J., and de Oliveira, M. C. N. 2017. Biology and nutrition of Spodoptera frugiperda (Lepidoptera: Noctuidae) fed on different food sources. Sci. Agric. 74:18-31.

De Groote, H., Oloo, F., Tongruksawattana, S., and Das, B. 2016. Communitysurvey based assessment of the geographic distribution and impact of maize lethal necrosis (MLN) disease in Kenya. Crop Prot. 82:30-35.

de Gruyter, H., Woudenberg, J. H. C., Aveskamp, M. M., Verkley, G. J. M., Groenewald, J. Z., and Crous, P. W. 2013. Redisposition of phoma-like anamorphs in Pleosporales. Stud. Mycol. 75:1-36.

Desjardins, M. L. 2010. 2009 Manitoba Crop Diagnostic Centre Laboratory submissions. Pages 20-27 in: Canadian Plant Disease Survey. R. A. A. Morrall, ed. Canadian Phytopathological Society.

Desjardins, M. L., and Bisht, V. 2011. 2010 Manitoba Crop Diagnostic Centre Laboratory submissions. Pages 22-30 in: Canadian Plant Disease Survey. R. A. A. Morrall, ed. Canadian Phytopathological Society.

Desjardins, M. L., Bisht, V., Deol, N., and Derksen, H. 2012. 2011 Manitoba Crop Diagnostic Centre Laboratory submissions. Pages 31-39 in: Canadian Plant Disease Survey. R. A. A. Morrall, ed. Canadian Phytopathological Society.

Desjardins, M. L., Bisht, V., and Derksen, H. 2013. 2012 Manitoba Crop Diagnostic Centre Laboratory submissions. Pages 37-44 in: Canadian Plant Disease Survey. R. A. A. Morrall, ed. Canadian Phytopathological Society.

Desjardins, M. L., Heard, J., Kaminski, D. A., and Northover, P. R. 2007. 2006 Manitoba Crop Diagnostic Centre Laboratory submissions. Pages 20-26 in: Canadian Plant Disease Survey. R. A. A. Morrall, ed. Canadian Phytopathological Society.

Desjardins, M. L., Kaminski, D. A., Keyworth, S. L., and Shinners-Carnelley, T. 2002. 2001 Manitoba Crop Diagnostic Centre Laboratory submissions. Pages 22-30 in: Canadian Plant Disease Survey. R. A. A. Morrall, ed. Canadian Phytopathological Society.

Desjardins, M. L., Kaminski, D. A., Northover, P. R., and Selvanathan, N. 2004. 2003 Manitoba Crop Diagnostic Centre Laboratory submissions. Pages 18-27 in: Canadian Plant Disease Survey. R. A. A. Morrall, ed. Canadian Phytopathological Society.

Desjardins, M. L., Kaminski, D. A., Northover, P. R., and Shinners-Carnelley, T. 2003. 2002 Manitoba Crop Diagnostic Centre Laboratory submissions. Pages 19-27 in: Canadian Plant Disease Survey. R. A. A. Morrall, ed. Canadian Phytopathological Society.

Desjardins, M. L., Kaminski, D. A., Northover, P. R., and Shinners-Carnelley, T. 2005. 2004 Manitoba Crop Diagnostic Centre Laboratory submissions. Pages 7-13 in: Canadian Plant Disease Survey. R. A. A. Morrall, ed. Canadian Phytopathological Society.

Desjardins, M. L., Kaminski, D. A., Northover, P. R., and Shinners-Carnelley, T. 2006. 2005 Manitoba Crop Diagnostic Centre Laboratory submissions. Pages 18-26 in: Canadian Plant Disease Survey. R. A. A. Morrall, ed. Canadian Phytopathological Society.

Desjardins, M. L., Northover, P. R., and Shinners-Carnelley, T. 2008. 2007 Manitoba Crop Diagnostic Centre Laboratory submissions. Pages 11-18 in: Canadian Plant Disease Survey. R. A. A. Morrall, ed. Canadian Phytopathological Society.

Desjardins, M. L., Northover, P. R., and Shinners-Carnelley, T. 2009. 2008 Manitoba Crop Diagnostic Centre Laboratory submissions. Pages 21-28 in: Canadian Plant Disease Survey. R. A. A. Morrall, ed. Canadian Phytopathological Society.

Desjardins, M. L., Pradhan, M., and Bisht, V. 2014. 2013 Manitoba Crop Diagnostic Centre Laboratory submissions. Pages 37-44 in: Canadian Plant Disease Survey. R. A. A. Morrall, ed. Canadian Phytopathological Society.

Desjardins, M. L., Pradhan, M., Bisht, V., and Derksen, H. 2015. 2014 Manitoba Crop Diagnostic Centre Laboratory submissions. Pages 25-32 in: Canadian Plant Disease Survey. R. A. A. Morrall, ed. Canadian Phytopathological Society.

Díaz-Cruz, G. A., and Cassone, B. J. 2018. A tale of survival: molecular defense mechanisms of soybean to overcome Soybean mosaic virus infection. Physiol. Mol. Plant. Pathol. 102:79-87.

Díaz-Cruz, G. A., Smith, C. M., Wiebe, K. F., and Cassone, B. J. 2017. First complete genome sequence of Tobacco necrosis virus $D$ isolated from soybean and from North America. Genome Announc. 5:e00781-17.

Díaz-Cruz, G. A., Smith, C. M., Wiebe, K. F., Charette, J. M., and Cassone, B. J. 2018. First report of Brome mosaic virus infecting soybean, isolated in Manitoba, Canada. Plant Dis. 102:460.
Dickinson, M. 2003. Molecular Plant Pathology. BIOS Scientific, London, UK. Domier, L. L., Steinlage, T. A., Hobbs, H. A., Wang, Y., Herrera-Rodriguez, G. Haudenshield, J. S., McCoppin, N. K., and Hartman, G. L. 2007. Similarities in seed and aphid transmission among Soybean mosaic virus isolates. Plant Dis. 91:546-550.

Duczek, L. J., Sutherland, K. A., Reed, S. L., Bailey, K. L., and Lafond, G. P. 1999. Survival of leaf spot pathogens on crop residues of wheat and barley in Saskatchewan. Can. J. Plant Pathol. 21:165-173.

Eichmeier, A., Komínková, M., Komínek, P., and Baránek, M. 2016 Comprehensive virus detection using next generation sequencing in grapevine vascular tissues of plants obtained from the wine regions of Bohemia and Moravia (Czech Republic). PLoS One 11:e0167966.

Fang, Y., and Ramasamy, R. P. 2015. Current and prospective methods for plant disease detection. Biosensors (Basel) 5:537-561.

Feng, Y., Krueger, E. N., Liu, S., Dorman, K., Bonning, B. C., and Miller, W. A. 2017. Discovery of known and novel viral genomes in soybean aphid by deep sequencing. Phytobiomes. 1:36-45.

Fernando, W., Zhang, X., and Amarasinghe, C. 2016. Detection of Leptosphaeria maculans and Leptosphaeria biglobosa causing blackleg disease in canola from Canadian canola seed lots and dockage. Plants 5:12.

Frowd, J. A., and Bernier, C. C. 1977. Virus diseases of faba beans in Manitoba and their effects on plant growth and yield. Can. J. Plant Sci. 57:845-852.

Garibyan, L., and Nidhi, A. 2013. Polymerase chain reaction. J. Invest. Dermatol. 133:1-4.

Gavloski, J. 2016. Summary of Insects on Crops in Manitoba in 2016. Carman, MB, Canada.

Gilbert, J., and Woods, S. M. 2001. Leaf spot diseases of spring wheat in southern Manitoba farm fields under conventional and conservation tillage. Can. J. Plant Sci. 81:551-559.

Golnaraghi, A. R., Shahraeen, N., Pourrahim, R., Farzadfar, S., and Ghasemi, A. 2004. Occurrence and relative incidence of viruses infecting soybeans in Iran. Plant Dis. 88:1069-1074.

Gomes, R. R., Glienke, C., Videira, S. I. R., Lombard, L., Groenewald, J. Z., and Crous, P. W. 2013. Diaporthe: A genus of endophytic, saprobic and plant pathogenic fungi. Persoonia Mol. Phylogeny Evol. Fungi. 31:1-41.

Gotoh, T., Suwa, A., and Kitashima, Y. 2004. Development and oviposition of Tetranychus pueraricola Ehara and Gotoh (Acari: Tetranychidae) on various plants. J. Acarol. Soc. Jpn. 13:135-140.

Groves, C., German, T., Dasgupta, R., Mueller, D., and Smith, D. L. 2016. Seed transmission of Soybean vein necrosis virus: The first Tospovirus implicated in seed transmission. PLoS One 11:e0147342.

Hadidi, A., Flores, R., Candresse, T., and Barba, M. 2016. Next-generation sequencing and genome editing in plant virology. Front. Microbiol. 7: 1325.

Han, J., Domier, L. L., Cassone, B. J., Dorrance, A., and Qu, F. 2016. Assessment of common soybean-infecting viruses in Ohio, USA, through multi-site sampling and high-throughput sequencing. Plant Health Prog. 17:133-140.

Hartman, G. L., Rupe, J. C., Sikora, E. J., Domier, L. L., Davis, J. A., and Steffey, K. L. 2015. Compendium of Soybean Diseases and Pests, 5th ed. American Phytopathological Society, St. Paul, MN.

Hayden, K. J., Garbelotto, M., Knaus, B. J., Cronn, R. C., Rai, H., and Wright, J. W. 2014. Dual RNA-seq of the plant pathogen Phytophthora ramorum and its tanoak host. Tree Genet. Genomes 10:489-502.

Henson, J., and French, R. 1993. The polymerase chain reaction and plant disease diagnosis. Annu. Rev. Phytopathol. 31:81-109.

Islam, M. T., Croll, D., Gladieux, P., Soanes, D. M., Persoons, A., Bhattacharjee, P., Hossain, M. S., Gupta, D. R., Rahman, M. M., Mahboob, M. G., and Cook, N. 2016. Emergence of wheat blast in Bangladesh was caused by a South American lineage of Magnaporthe oryzae. BMC Biol. 14:84.

Jasnić, S. M., Marjanović, Ž. S., Vidić, M. B., Bagi, F. F., Budakov, D. B. Pavlović, S. Đ., and Stojšin, V. B. 2011. Pathogenic, morphological and molecular characteristics of Alternaria tenuissima from soybean. Zb. Matice Srp. za Prir. Nauk. 120:183-196.

Kehoe, M. A., Coutts, B. A., Buirchell, B. J., and Jones, R. A. C. 2014. Plant virology and next generation sequencing: Experiences with a Potyvirus. PLoS One 9:e104580.

Keough, S., Han, J., Shuman, T., Wise, K., and Nachappa, P. 2016. Effects of soybean vein necrosis virus on life history and host preference of its vector, Neohydatothrips variabilis, and evaluation of vector status of Frankliniella tritici and Frankliniella fusca. J. Econ. Entomol. 109:1979-1987.

Larran, S., Rollán, C., Ángeles, H. B., Alippi, H. E., and Urrutia, M. I. 2002. Endophytic fungi in healthy soybean leaves. Prod. Protección Veg. 17: 173-178

Lima, J. A. A., Nascimento, A. K. Q., Radaelli, P., and Purcifull, D. E. 2012. Serology applied to plant virology. Pages 72-94 in: Serological Diagnosis of Certain Human, Animal and Plant Diseases. M. Al-Moslih, ed. InTech, London, UK.

López, M. M., Bertolini, E., Olmos, A., Caruso, P., Gorris, M. T., Llop, P. Penyalver, R., and Cambra, M. 2003. Innovative tools for detection of plant pathogenic viruses and bacteria. Int. Microbiol. 6:233-243.

Mahuku, G., Lockhart, B. E., Wanjala, B., Jones, M. W., Kimunye, J. N. Stewart, L. R., Cassone, B. J., Sevgan, S., Nyasani, J. O., Kusia, E., and Kumar, P. L. 2015. Maize lethal necrosis (MLN), an emerging threat to 
maize-based food security in Sub-Saharan Africa. Phytopathology 105: 956-965.

Manamgoda, D. S., Rossman, A. Y., Castlebury, L. A., Crous, P. W., Madrid, H., Chukeatirote, E., and Hyde, K. D. 2014. The genus Bipolaris. Stud. Mycol. 79: 221-288.

Marzano, S.-Y. L., and Domier, L. L. 2016. Novel mycoviruses discovered from metatranscriptomics survey of soybean phyllosphere phytobiomes. Virus Res. 213:332-342.

McCartney, H. A., Foster, S. J., Fraaije, B. A., and Ward, E. 2003. Molecular diagnostics for fungal plant pathogens. Pest Manag. Sci. 59:129-142.

Mengistu, A., Castlebury, L. A., Morel, W., Ray, J. D., and Smith, J. R. 2014. Pathogenicity of Diaporthe spp. isolates recovered from soybean (Glycine max) seeds in Paraguay. Can. J. Plant Pathol. 36:470-474.

Muir, P., Li, S., Lou, S., Wang, D., Spakowicz, D. J., Salichos, L., Zhang, J., Weinstock, G. M., Isaacs, F., Rozowsky, J., and Gerstein, M. 2016. The real cost of sequencing: Scaling computation to keep pace with data generation. Genome Biol. 17:1-9.

Narayanasamy, P. 2011. Molecular techniques for detection of microbial pathogens. Pages 7-158 in: Molecular Biology in Plant Pathogenesis and Disease Management. Springer, Dordrecht, The Netherlands.

Nevena, M., Jelena, V., and Franić-Mihajlović, D. 1997. A comparative study of Diaporthe/Phomopsis fungi on soybean from two different regions of the world. Mycopathologia 139:107-113.

Nikolova, I., Georgieva, N., and Naydenova, J. 2014. Development and reproduction of spider mites Tetranychus turkestani (Acari: Tetranychidae) under water deficit condition in soybeans. Pestic. Fitomedicina. 29:187195.

Nouri, S., Salem, N., Nigg, J. C., and Falk, B. W. 2016. Diverse array of new viral sequences identified in worldwide populations of the Asian citrus psyllid (Diaphorina citri). Using Viral Metagenomics. J. Virol. 90:2434-2445.

Nowell, R. W., Laue, B. E., Sharp, P. M., and Green, S. 2016. Comparative genomics reveals genes significantly associated with woody hosts in the plant pathogen Pseudomonas syringae. Mol. Plant Pathol. 17:1409-1424.

Ortíz-Castro, R., Contreras-Cornejo, H. A., Macías-Rodríguez, L., and LópezBucio, J. 2009. The role of microbial signals in plant growth and development. Plant Signal. Behav. 4:701-712.

Peruca, R. D., Coelho, R. G., da Silva, G. G., Pistori, H., Ravaglia, L. M., Roel, A. R., and Alcantara, G. B. 2018. Impacts of soybean-induced defenses on Spodoptera frugiperda (Lepidoptera: Noctuidae) development. ArthropodPlant Interact. 12:257-266.

Petrović, K., Vidić, M., Riccioni, L., Đorđević, V., and Rajković, D. 2015. First report of Diaporthe eres species complex causing seed decay of soybean in Serbia. Plant Dis. 99:1186.

Platford, R. G., and Desjardins, M. L. 1999. 1998 Manitoba Crop Diagnostic Centre Laboratory submissions. Pages 39-53 in: Canadian Plant Disease Survey. R. A. A. Morrall, ed. The Canadian Phytopathological Society

Platford, R. G., and Desjardins, M. L. 2000. 1999 Manitoba Crop Diagnostic Centre Laboratory submissions. Pages 24-31 in: Canadian Plant Disease Survey. R. A. A. Morrall, ed. The Canadian Phytopathological Society

Platford, R. G., and Kurtz, R. 1997. Diseases diagnosed on commercial and special crops and ornamental trees and shrubs submitted to the Manitoba Crop Diagnostic Centre Laboratory in 1996. Pages 28-36 in: Canadian Plant Disease Survey. L. W. Stobbs, ed. Canadian Phytopathological Society.

Platford, R. G., and Kurtz, R. 1998. 1997 Manitoba Crop Diagnostic Centre Laboratory submissions. Pages 33-44 in: Canadian Plant Disease Survey. L. W. Stobbs, ed. Canadian Phytopathological Society.

Pobozniak, M. 2011. The occurrence of thrips (Thysanoptera) on food legumes (Fabaceae). J. Plant Dis. Prot. 118:185-193.

Porto, M. D. M., and Hagedorn, D. J. 1975. Seed transmission of a Brazilian isolate of Soybean mosaic virus. Phytopathology 65:713-716.

Pradhan, M., Bisht, V., and Bajracharya, P. 2016. 2015 Manitoba Crop Diagnostic Centre Laboratory submissions. Pages 33-40 in: Canadian Plant Disease Survey. R. A. A. Morrall, ed. Canadian Phytopathological Society.

Pradhan, M., Bisht, V., Derksen, H., and Bajracharya, P. 2017. 2016 Manitoba Agriculture Crop Diagnostic Centre Laboratory submissions. Pages 33-40 in: Canadian Plant Disease Survey. J. Elmhirst, ed. Canadian Phytopathological Society.

Qi, M., Wang, D., Bradley, C. A., and Zhao, Y. 2011. Genome sequence analyses of Pseudomonas savastanoi pv. glycinea and subtractive hybridizationbased comparative genomics with nine pseudomonads. PLoS One 6:e16451.

Ray, M., Ray, A., Dash, S., Mishra, A., Achary, K. G., Nayak, S., and Singh, S. 2017. Fungal disease detection in plants: Traditional assays, novel diagnostic techniques and biosensors. Biosens. Bioelectron. 87:708-723.

Rimmer, S. R., Shattuck, V. I., and Buchwaldt, L. 2007. Compendium of Brassica Diseases. American Phytopathological Society, St. Paul, MN.

Santos, J. M., Vrandečić, K., Ćosić, J., Duvnjak, T., and Phillips, A. J. L. 2011. Resolving the Diaporthe species occurring on soybean in Croatia. Persoonia Mol. Phylogeny Evol. Fungi. 27:9-19.

Schumann, G. L., and D'Arcy, C. J. 2012. What is wrong with my plant? Pages 1-20 in: Essential Plant Pathology. American Phytopathological Society, St. Paul, MN
Shokralla, S., Porter, T. M., Gibson, J. F., Dobosz, R., Janzen, D. H., Hallwachs, W., Golding, G. B., and Hajibabaei, M. 2015. Massively parallel multiplex DNA sequencing for specimen identification using an Illumina MiSeq platform. Sci. Rep. 5:9687.

Shortt, B. J., Sinclair, J. B., Helm, C. G., Jeffords, M. R., and Kogan, M. 1982 Soybean seed quality losses associated with bean leaf beetles and Alternaria tenuissima. Phytopathology 72:615-618.

Soares, A. P. G., Guillin, E. A., Borges, L. L., da Silva, A. C. T., de Almeida, Á. M. R., Grijalba, P. E., Gottlieb, A. M., Bluhm, B. H., and de Oliveira, L. O. 2015. More Cercospora species infect soybeans across the Americas than meets the eye. PLoS One 10:e0133495.

Statistics Canada. 2018. Table 32-10-0359-01: Estimated areas, yield, production, average farm price and total farm value of principal field crops, in metric and imperial units, annual. https://www150.statcan.gc.ca/t1/tbl1/en/tv.action?pid= 3210035901

Stewart, L. R., Teplier, R., Todd, J. C., Jones, M. W., Cassone, B. J., Wijeratne, S., Wijeratne, A., and Redinbaugh, M. G. 2014. Viruses in maize and johnsongrass in Southern Ohio. Phytopathology 104:1360-1369.

Studholme, D. J., Glover, R. H., and Boonham, N. 2011. Application of highthroughput DNA sequencing in phytopathology. Annu. Rev. Phytopathol. 49: 87-105.

Stukenbrock, E. H., and McDonald, B. A. 2008. The origins of plant pathogens in agro-ecosystems. Annu. Rev. Phytopathol. 46:75-100.

Suekane, R., Degrande, P. E., Pontes de Melo, E., Bertoncello, T. F., dos Santos de Lima, I., Jr., and Kodama, C. 2012. Damage level of the two-spotted spider mite Tetranychus urticae Koch (Acari: Tetranychidae) in soybeans. Rev. Ceres 59: 77-81.

Thomma, B. P. H. J. 2003. Alternaria spp.: From general saprophyte to specific parasite. Mol. Plant Pathol. 4:225-236.

Timilsina, S., Adkison, H., Testen, A. L., Newberry, E. A., Miller, S. A., Paret, M L., Minsavage, G. V., Goss, E. M., Jones, J. B., and Vallad, G. E. 2017. A novel phylogroup of Pseudomonas cichorii identified following an unusual disease outbreak on tomato. Phytopathology 107:1298-1304.

Trigiano, R. N., Windham, M. T., and Windham, A. S. 2004. Plant Pathology: Concepts and Laboratory Exercises. CRC Press, Boca Raton, FL.

$\mathrm{Tu}$, J. C. 1986. Incidence of soybean mosaic virus and tobacco ringspot virus in southwestern Ontario. Can. Plant Dis. Surv. 66:49-50.

Turner, T. R., James, E. K., and Poole, P. S. 2013. The plant microbiome. Genome Biol. 14:209.

Tyler, B. M. 2007. Phytophthora sojae: Root rot pathogen of soybean and model oomycete. Mol. Plant Pathol. 8:1-8.

Udayanga, D., Castlebury, L. A., Rossman, A. Y., Chukeatirote, E., and Hyde, K. D. 2014. Insights into the genus Diaporthe: Phylogenetic species delimitation in the D. eres species complex. Fungal Divers. 67:203-229.

Udayanga, D., Castlebury, L. A., Rossman, A. Y., Chukeatirote, E., and Hyde, K. D. 2015. The Diaporthe sojae species complex: Phylogenetic re-assessment of pathogens associated with soybean, cucurbits and other field crops. Fungal Biol. 119:383-407.

Untergasser, A., Cutcutache, I., Koressaar, T., Ye, J., Faircloth, B. C., Remm, M. and Rozen, S. G. 2012. Primer3-new capabilities and interfaces. Nucleic Acids Res. 40:e115.

Verkley, G. J. M., Quaedvlieg, W., Shin, H.-D., and Crous, P. W. 2013. A new approach to species delimitation in Septoria. Stud. Mycol. 75:213-305.

Vicente, J. G., and Holub, E. B. 2013. Xanthomonas campestris pv. campestris (cause of black rot of crucifers) in the genomic era is still a worldwide threat to brassica crops. Mol. Plant Pathol. 14:2-18

Videira, S. I. R., Groenewald, J. Z., Nakashima, C., Braun, U., Barreto, R. W., de Wit, P. J. G. M., and Crous, P. W. 2017. Mycosphaerellaceae-chaos or clarity? Stud. Mycol. 87:257-421.

Viteri, D., Cabrera, I., and Estévez de Jensen, C. 2010. Identification and abundance of thrips species on soybean in Puerto Rico. Int. J. Trop. Insect Sci. 30:57.

Westermann, A. J., Gorski, S. A., and Vogel, J. 2012. Dual RNA-seq of pathogen and host. Nat. Rev. Microbiol. 10:618-630.

Wisler, G. C., and Norris, R. F. 2005. Interactions between weeds and cultivated plants as related to management of plant pathogens. Weed Sci. 53: 914-917.

Wrather, A., Shannon, G., Balardin, R., Carregal, L., Escobar, R., Gupta, G. K., Ma, Z., Morel, W., Ploper, D., and Tenuta, A. 2010. Effect of diseases on soybean yield in the top eight producing countries in 2006. Plant Health Prog. 10:2008-2013.

Wrather, J. A., and Koenning, S. R. 2006. Estimates of disease effects on soybean yields in the United States 2003 to 2005. J. Nematol. 38:173-180.

Yorinori, J. T., Paiva, W. M., Frederick, R. D., Costamilan, L. M., Bertagnolli, P. F., Hartman, G. E., Godoy, C. V., and Nunes, J., Jr. 2005. Epidemics of soybean rust (Phakopsora pachyrhizi) in Brazil and Paraguay from 2001 to 2003. Plan Dis. 89:675-677.

Yu, S. M., and Lee, Y. H. 2012. First report of Pseudomonas cichorii associated with leaf spot on soybean in South Korea. Plant Dis. 96:142.

Zhang, G. R., Newman, M. A., and Bradley, C. A. 2012. First report of the soybean frogeye leaf spot fungus (Cercospora sojina) resistant to quinone outside inhibitor fungicides in North America. Plant Dis. 96:767.

Zhang, J., Chiodini, R., Badr, A., and Zhang, G. 2011. The impact of next-generation sequencing on genomics. J. Genet. Genomics 38:95-109. 